\title{
理学療法学科学生の大学生活における不安 \\ 一一学生活不安尺度による検討一一 \\ Anxiety of the Students of a Department of Physical Therapy Connected to Their Campus Life: Research Using College Life Anxiety Scale
}

\begin{abstract}
菅沼 一男 ${ }^{1)}$ 平林 茂 ${ }^{1)}$ 大日向 浩 ${ }^{1)}$ 金子 千香1)
Kazuo SUGANUMA, RPT ${ }^{1)}$, Shigeru HIRABAYASHI, MD, PhD ${ }^{1)}$, Hiroshi OHINATA, $\mathrm{PhD}^{1)}$, ChiKa KANEKO, RPT ${ }^{1)}$

1) Department of Tokyo Physical Therapy, Faculty of Medical Science, Teikyo University of Science: 2-2-1 Senjyusakuragi, Adachi-ku, Tokyo 120-0045, Japan.TEL+813-6910-1010E-mail: suganuma@ntu.ac.jp
\end{abstract}

Rigakuryoho Kagaku 30(2): 193-196, 2015. Submitted Oct. 6, 2014. Accepted Nov. 19, 2014.

\begin{abstract}
Purpose] To investigate the anxiety with campus life of department of physical therapy students. [Subjects] Seventy third-year university students, facing long-term practical training outside the campus. [Methods] The students were surveyed using the college life anxiety scale. [Results] In the comparison of students repeating the same year with those who were not, uneasiness with everyday life was higher in the former. In the comparison of males and females, uneasiness with everyday life and the total anxiety assessment were higher among males, and maladjustment to university was higher among females. [Conclusion] Because uneasiness with everyday life is higher among students repeating the same year, support for these students is especially necessary. In this study, longterm practical training outside the campus was considered to have influenced students' uneasiness with everyday life; therefore, it will be necessary to confirm the chronological changes by comparing students' conditions between preand post-practice.
\end{abstract}

Key words: college life anxiety scale, anxiety, physical therapy

要旨：〔目的〕理学療法学科に在籍する学生の大学生活不安を調査することとした。〔対象〕4 年制大学の理学療法学 科 3 年次に在籍し, 長期臨床実習を間近に控えた 70 名の学生.〔方法〕集合調査法による回答から得られた大学生活 不安尺度を留年未経験者からなる群と経験した者からなる群との間で比較した。〔結果〕留年経験者の群の日常生活 不安が未経験者の群に比べてょり高值を示した，男女の比較では，日常生活不安の程度と総合得点で男性が高值を示 し，大学不適応の程度では女性が高值を示した。〔結語〕留年を経験すると日常生活不安が高くなることから，これ らの学生に対する支援が必要である。また，臨床実習が大学生活不安に影響を及ぼす一因と推測されることから，実 習後との比較など経時的変化の検討を行う必要がある.

キ一ワード : 大学生活不安尺度, 不安, 理学療法

\footnotetext{
1) 帝京科学大学 医療科学部 東京理学療法学科: 東京都足立区千住桜木 2-2-1 ( ₹ 120-0045) TEL 03-6910-1010 


\section{I.はじめに}

近年は, 大学数の増加と高校生数の減少とが相まって, 「大学全入時代」を迎えており，言い換えれば，好みを 言わなければ誰もがどこかの大学へ入れる時代となっ た。しかし,この結果, 明確な目的意識や自らの将来の 展望を持たずに大学へ入学し, 入学後に改めて, その意 義を問い直したうえで「進路変更」や「一身上の都合」 を理由に，大学を中退する学生が増加していると言われ ている。この「一身上の都合」の中には，学業や人間関 係の問題から授業を欠席しがちとなり, 大学不適応をお こして休学, 留年, そして最終的には退学していくとい う実情も含まれていると考えられる。田 ${ }^{1)}$ は，大学 1 年生から 4 年生までの 4,070 名を対象に調査した結果, 全体の $45.7 \%$ が不本意な入学や学業面でのつまずき, 友人関係の問題を抱え他大学への再入学を希望している と報告している。

最近は, 我が国の社会に扔ける高齢化の一層の進行と、 大学生の就職難とを反映して，医療系の資格を取得する 目的で医療系学科を受験する学生が増加している。 しか し，医療系学科では医療の専門家を養成するカリキュラ ムが組まれて抢り, 膨大な知識や技術の習得や臨床実習 が課せられ，卒業直前まで国家試験に備えて，学習しな ければならない，また，臨床実習では，学力のみでなく コミュニケーション能力も問われることが多い. 学力や コミュニケーション能力に問題のある学生は, 定期試験, 臨床実習がクリアできずに大学不適応を抢こし, 結果と して, その進路が留年や退学に結び付きやすいと考えら れている。 このため, 大学不適応を起こしている学生を 早期に発見し, 支援または適切な進路変更へのアドバイ スを行うことは, 当該学生のみならず, ともに学んでい る周囲の学生や, 教育の場を提供している大学にとって も重要な課題である.

医療系学科は, 生体を対象とする職種に就くための学 科であることから, 他学科と比べて進級要件が厳しいと 考えられ, このため, 学生の多くが学生生活に不安を抱 えやすい傾向があることが予測される。しかし，これま で, 大学生の学生生活不安についての報告は, ほとんど が医療系学科以外を対象としたものであり, 我々が渉猟 した範囲では，医療系学科を対象とした報告はなかっ た.

本研究の目的は, 理学療法学科に在籍する学生を対象 として, 大学生活不安尺度を用いて, 大学生活に扔ける 不安についての実態調査を行うことである.

\section{II. 対象と方法}

1. 対象

対象は, 4 年制大学の理学療法学科 3 年次に在籍し,
8 週間におよぶ長期臨床実習を間近に控えた学生 70 名 （男性 36 名，女性 34 名）で, 平均年齢は $21.3 \pm 0.5$ 歳 であった，そのうち, 留年の経験者（以下, 留年経験群) は20 名（男性 16 名，女性 4 名）であった。

\section{2. 方法}

大学生活不安尺度 (College Life Anxiety Scale 以下, CLAS）とは，(1）大学の日常生活に対する不安感，(日 常生活不安; 14 項目)，（2）大学に扔ける単位や試験に 対する不安感 (評価不安; 11 項目), (3)「不登校」や「中 退」といった就学上の問題を生じさせる大学不適応感 (大学不適応； 5 項目）の 30 項目の設問から構成される. 回答は,「はい」,「いいえ」の 2 件法で求め, 不安傾向 に該当する方向へのものを各 1 点とし, CLAS プロ フィール得点換算表にて得点を換算する。この得点が高 いほど不安を抱えていることを示す，なお，CLAS の信 頼性，妥当性についての検証はすでになされている11).

対象者に対し集合調査法にて，この尺度の評価を実施 した．まず，「指示があるまで始めないように」と指示し 大学の成績に影響することは全くないので, 安心してあ りのまま回答するよう説明した。 その後, 必要事項（検 査日, 学籍番号, 学年, 性別, 氏名) を記載してもらい, 開始の合図で回答を開始させた．また，全員の回答が終 わるまで私語を慎むように指示した。

順調に進級した留年未経験の群（以下, 現役群）と留 年経験群との間拉よび男女間の比較を行った。統計学的 解析は, 各検定に先立ち Shapiro-Wilk 検定㧍よび等分 散性の検定を行い，正規性扔よび等分散性が確認された 時は，対応のない $\mathrm{t}$ 検定を用い，それ以外の時は MannWhitneyのU 検定を用いた。統計ソフトウェアは PASW statistics 18 (SPSS Japan) を使用し, 危険率 5\% 未満をもって有意と判断した。

な押, 本研究は, 帝京科学大学の倫理審査委員会で認 可されたあと, 対象者には本研究の意義と大学の成績に 影響することは全くないことを説明し同意を得た上で実 施した。

\section{III. 結 果}

現役群と留年経験群の比較では, 日常生活不安が, 留 年経験群 $71.5 \pm 15.0$ (平均值 \pm 標準偏差), 現役群 $60.6 \pm 13.9$ であり, 留年経験群が有意に高值を示した。 評価不安, 大学不適応, 全体得点は両群間に差が認めら れなかった，男女の間の比較では，日常生活不安が男性 $72.6 \pm 15.2$, 女性 $54.2 \pm 6.5$, 全体得点が男性 $65.6 \pm$ 15.4, 女性 $56.8 \pm 8.3$ であり男性が有意に高值を示し, 一方で大学不適応では男性が $48.7 \pm 7.0$, 女性 $55.9 \pm$ 10.0 であり女性が高值を示した（表 1). 
表 1 留年経験の有無および男女の間の大学生活不安尺度の比較

\begin{tabular}{lllll}
\hline & \multicolumn{1}{c}{ 留年生 } & \multicolumn{1}{c}{ 現役生 } & \multicolumn{1}{c}{ 男性 } & 女性 \\
\hline 日常生活不安 & $71.5 \pm 15.0^{*}$ & $60.6 \pm 13.9$ & $72.6 \pm 15.2 *$ & $54.2 \pm 6.5$ \\
評価不安 & $58.9 \pm 12.1$ & $56.7 \pm 13.1$ & $58.5 \pm 13.9$ & $56.1 \pm 11.6$ \\
大学不適応 & $52.3 \pm 8.5$ & $52.1 \pm 9.7$ & $48.7 \pm 7.0^{*}$ & $55.9 \pm 10.0$ \\
全体得点 & $64.0 \pm 10.7$ & $60.2 \pm 13.9$ & $65.6 \pm 15.4 *$ & $56.8 \pm 8.3$ \\
\hline
\end{tabular}

平均值 \pm 標準偏差. $*: \mathrm{p}<0.05$.

\section{IV. 考 察}

現在わが国では，大学への進学が $50 \%$ を越え，専門 学校などの高等教育機関を含めると $70 \%$ 学生が進学 をしている，そのため, 高等教育機関では, 学生確保の ために早期から様々な形態の入学試験を実施している. 多様化した入学試験の実施は, 個性や高校生活を評価で きる方法である反面, 十分な学力や目的意識のない学生 を入学させてしまう危険性も伴う。藤井 2) は，必ずし も十分な学力水準に到達していない学生が多く入学する ようになってきており，また，集団に馴染めず，人間関 係に息苦しさを感じ孤立する学生も増えてきており, こ のことが, 大学不適応傾向の学生が増加する原因となっ ていると述べている。したがって，大学は大学生活にお ける不安を分析し, 問題のある学生を早期に発見し, 支 援することが必要である.

本研究は, 理学療法学科に在籍する 3 年生を対象に, 大学生活における不安について CLAS を用いて検討し た。まず，留年経験群と現役群の比較では，留年経験群 が日常生活不安の程度で高值を示した。 日常生活不安は， 「無事に単位を取れるか」，「卒業できるか」などを気に する進級や卒業に関する設問や，「大学で人が自分のこ とをどう思っているか」, 「友達と一緒に何かしなければ ならない時にうまく協力してできるか不安な気持ちにな る」などの対人関係に関する設問である。留年経験者は, 留年経験により進級や卒業のことを気に掛けることが多 く，留年により新たな人間関係を構築することへの，ま た，他人が留年した自分をどのように見ているのかなど に対する不安を感じやすく，このことが留年経験群の日 常生活不安を強くしている一因であると考えられる。

次に, 男女差をみると, 日常生活不安および全体得点 で男性が高值を示した，藤井 3）は，関東地方にある国 立大学 5 校および私立大学 5 校の 2,782 名を対象とした 調査において, 女子学生の方が男子学生よりも日常生活 不安を強く感じていると述べている。 また, 山田4)は, 男子で高不安者が少ないのに対して，女子で多いと述心゙ ている. 一方で, 徳田 ${ }^{5)}$ は, 4 年制大学生で, 田中 6) は, 教育学部の学生で高不安者数の性差を認めなかったと述 べており，性差については，これまで一定の見解は得ら れていない，女性に比べ男性が日常生活不安を感じてい
るとの本研究には, 留年経験群の多くが男性であること が影響したのではないかと考えられる。また，この性差 が全体得点で男性が高い值を示すことにつながったもの と思われた。

一方，女性は大学不適応において高值を示した。 大学 不適応とは,「この大学にいると何か不安になる」,「こ んな大学にいたら自分がだめになる」と言った不安であ る。久保 7) は，女性は男性よりも「専門的知識や技術 の習得」を重視し，学業不安が弱い代わりに卒業後の不 安を強く，また早くから感じていると述べている。本研 究の実施は, 3 年生の終わりの時期であり, 数週間後に は, 長期臨床実習や国家試験対策, 就職活動などのこと を考えなくてはならない時期であったことから，そのこ とが，この結果に影響を及ぼしたのではないかと考えら れる。

学生期の 4 年間におこる心理的変化に関して, 徳田 ${ }^{5)}$ は，学科による違いがあると述べている。学科による大 学生活不安の相違について山田 ${ }^{4)}$ は, 情報系学科, 社 会科学系学科と管理栄養士課程の学生を対象にCLAS を実施し，管理栄養士課程では，男女とも日常生活不安， 評価不安, 全体得点において藤井 2)の報告している平 均より高くなっており, 大学生活にかかわる不安が強い と述べている。 その理由として，カリキュラムが必須科 目中心で自由度が低いものになりがちでかつ, 目標のた めに継続して努力することが求められること, 職業選択 の結果と自分の適性の一致性に疑問を持ち, その結果, 自信がゆらぐことによるとしている．

理学療法養成課程においても，管理栄養士課程と同様 に必須科目が多く, 職業選択をしてから入学をすること になる。このことから, 理学療法学科の学生は, 一般の 大学生に比べ卒業までに多くの課題に直面することとな る. 例えば, 1 年次では新しい生活への移行, 大学の力 リキュラム・授業への適応, 新しい人間関係の構築など 一般的な大学生と同様の課題が主であるが，2 年次から は, 本格的な専門科目の履修や検査・治療技術の習得, 3 年次では, はじめての臨床実習の履修, 4 年次では長 期臨床実習の履修, 卒業論文の作成, 国家試験対策, 就 職活動が挙げられる。理学療法学科では, 学年が上がる につれ，より専門的な学習となる上に，学外で臨床実習 が行われるために新しい環境に慣れることや新しい人間 
関係を構築した中で課題の遂行が求められる。一般的に 大学生活不安は，学年が上がるにつれ低下していくとい われている 3,6). 藤井 2) は不安の程度を示す得点が下が り，3 年生以上では 1 年生に比べて有意に低かったと述 べている. 本研究の対象者は 3 年生であり, 一般の大学 生では不安が低くなる学年ではあるが, 長期の臨床実習 を間近に控えており，この時期に調査を行ったことが結 果に影響していることも考えられる.

大学生活不安の原因は, 大学や学科ごとの特性により 異なるうえに, 人間関係や大学での課題などにも影響を 受けると考えられるため, 学生が不安を感じる要因につ いてさらに精査し, 個々に対応していく必要がある。特 に，留年経験者への支援が必要である.

今後は，各学年において授業実施期間，定期試験前な どの条件下での不安の程度の变動について検討をすると ともに, 入学期からの経年的な変化や入試形態などとの 関係について明らかにする必要がある。

\section{引用文献}

1) 山田剛史：大学生活について一大学生の生活体験と適応 意識一. ベネッセコーポレーション研究所報, 2009, 51: $58-63$.

2) 藤井義久：CLAS マニュアル，金子書房，東京，2013， pp1-23.

3) 藤井義久：大学生活不安尺度の作成および信頼性・妥当性 の検討. 心理学研究, 1998，68(6): 441-448.

4) 山田ゆかり：大学新入生に抢ける適応感の検討. 名古屋文 理大学紀要, 2006, 6: 29-36.

5) 徳田完二 : 学生期ライフサイクルからみた学生の不安, 4 年制大学生と短期大学生の違いについて. 人間福祉研究, 2005, 8: 179-188.

6) 田中 存, 菅 千索：大学生活不安に関する心理学からの アプローチ．和歌山大学教育学部紀要教育科学, 2007, 57: $15-22$.

7) 久保光正, 徳田完二 : 心身両面からみた学生期のライフサ イクル，北海道大学紀要， 1999，49(2): 53-65. 